\title{
SCIENTIFIC REPORTS

\section{OPEN In Vitro and In Vivo Evaluation of the Anticancer and Anti-inflammatory Activities of 2-Himachelen-7-ol isolated from Cedrus Libani}

Received: 1 April 2019

Published online: 06 September 2019
Andree Elias ${ }^{1}$, Wassim N. Shebaby ${ }^{1}$, Bilal Nehme ${ }^{1}$, Wissam Faour $\mathbb{D}^{2}$, Bassem S. Bassil ${ }^{3}$, Joelle El Hakim ${ }^{1}$, Rita Iskandar ${ }^{1}$, Nahia Dib-Jalbout ${ }^{1}$, Mohamad Mroueh ${ }^{4}$, Costantine Daher ${ }^{1}$ \& Robin I. Taleb $\mathbb{D}^{1}$

Cedrus libani is a majestic evergreen tree native to the Mediterranean mountains of Lebanon, Syria and Turkey. In this study, the tree heart wood was extracted using hexane to produce $C$. libani oil extract (CLOE) as a dark oil. GCMS analysis of CLOE identified up to 30 compounds whereby 2-himachalen7-ol (7-HC) was the most abundant (40\%). 7-HC was isolated using column chromatography and the identity of the white crystalline solid was confirmed via NMR spectroscopy and X-Ray Crystallography. 7-HC demonstrated potent cytotoxic activity against several human cancer cell lines including brain $\left(\mathrm{SF}-268, \mathrm{IC}_{50} 8.1 \mu \mathrm{g} / \mathrm{mL}\right.$ ) and colon (HT-29, IC ${ }_{50} 10.1 \mu \mathrm{g} / \mathrm{mL}$; Caco-2, IC $50.9 \mu \mathrm{g} / \mathrm{mL}$ ) with ovarian (SkOV-3, IC $50>50 \mu \mathrm{g} / \mathrm{mL}$ ) cells being the most resistant. However, while HT-29 displayed resistance to Cisplatin, 7-HC was 8-10 folds more potent. Co-treatment with 7-HC and Cisplatin showed a significant synergistic anti-proliferative effect against SF-268, HT-29 and Caco-2 cells. 7-HC also exhibited significant anti-inflammatory effect in formalin-induced paw edema in rats. Western blot analysis revealed that 7-HC displayed dose dependent inhibition of LPS-induced COX-2 protein expression in isolated rat monocytes. The present study demonstrates that 7-HC possesses promising anticancer and anti-inflammatory activities, and may serve as a lead molecule in cancer therapy.

Phytomedicine have been heavily utilized in the treatment and the chemoprevention of various cancer types, due to the pro-apoptotic and anti-proliferative activities of numerous plant-derived compounds ${ }^{1}$. Among the current anticancer medications, more than $60 \%$ of drugs approved for cancer treatment between 1940 and 2002 have either been natural products or formulations based on natural products; a rate higher than any other area of drug development ${ }^{2}$.

The Lebanese Cedar (Cedrus libani, C. libani) is a conifer species native to the Mediterranean mountains of Lebanon and Syria as well as the Toros Mountains of Turkey ${ }^{3}$. Ethnobotanical and traditional uses of the Cedrus genus traces back to ancient times whereby its essential oil was used in traditional medicine ${ }^{4}$. Phytochemical analysis of oils extracted from several Cedrus species revealed that steroids, procyanidins and terpenoids are the major constituents ${ }^{5,6}$. These phytochemicals have been shown to possess a wide range of biological activities, such as anticancer ${ }^{7}$, anti-inflammatory ${ }^{8}$ and antimicrobial effects ${ }^{9}$. The wood oil of $C$. libani was shown to possess potent antitumor effect against K562 human chronic myelogenous leukemia cells, as well as against multi-drug resistant leukemia cells ${ }^{10,11}$. Additionally, the C. libani wood oil induced erythroid differentiation at the terminal phase which is known to stimulate the expression of fetal globin genes ${ }^{10}$. Remarkably, the oil did not display cross-resistance, and as such this phenomenon elevates the stature of $C$. libani oils as a promising source of natural active compounds that may be formulated into agents used for the treatment of drug-resistant leukemia and refractory tumors ${ }^{10}$.

Inflammation is a host defense mechanism to eradicate invading pathogens and to initiate the healing process, but the excessive production of inflammatory mediators may cause injury to host cells along with chronic

${ }^{1}$ Department of Natural Sciences, Lebanese American University, Byblos, 1102 2801, Lebanon. ${ }^{2}$ School of Medicine, Lebanese American University, Byblos, 1102 2801, Lebanon. ${ }^{3}$ Faculty of Arts and Sciences, University of Balamand, PO Box 100, Tripoli, Lebanon. ${ }^{4}$ School of Pharmacy, Lebanese American University, Byblos, 1102 2801, Lebanon. Correspondence and requests for materials should be addressed to R.I.T. (email: robin.taleb@lau.edu.lb) 


\begin{tabular}{|l|l|l|l|}
\hline Peak & RT & \% Area & Compound \\
\hline 1 & 4.597 & 0.0692 & $\beta$-Pinene \\
\hline 2 & 14.73 & 2.9642 & Q-Himachalene \\
\hline 3 & 15.83 & 3.1818 & $\gamma$-Himachalene \\
\hline 4 & 16.74 & 3.3695 & $\beta$-Himachalene \\
\hline 5 & 17.2 & 0.3641 & Butylated Hydroxytoluene \\
\hline 6 & 17.23 & 0.4236 & Butylated Hydroxytoluene \\
\hline 7 & 18.26 & 0.3495 & 1,1,2,2,3,3-Hexamethylindane \\
\hline 8 & 20.82 & 0.8447 & 4,4 -Dimethyl-3-(3-methylbut-3-enylidene)-2-methylenebicyclo[4.1.0]heptane \\
\hline 9 & 22.18 & 0.841 & 8-Himachalene \\
\hline 10 & 23.24 & 40.2246 & 2-Himachalen-7-ol \\
\hline 11 & 23.76 & 2.7206 & 1H-Benzocycloheptene \\
\hline 12 & 25.53 & 7.4441 & Dodecyl acrylate \\
\hline 13 & 34.25 & 0.9166 & (S)-Phenol, 2-methyl-5-(1,2,2-trimethylcyclopentyl) \\
\hline 14 & 38.16 & 0.9471 & Dibutyl phthalate \\
\hline 15 & 53.48 & 0.2794 & Methyl isopimarate \\
\hline 16 & 53.66 & 0.5158 & Abietadien-18-al \\
\hline 17 & 54.69 & 0.4301 & Methyl levopimarate \\
\hline 18 & 55.48 & 0.125 & Methyl abietate \\
\hline 19 & 55.91 & 0.3668 & Tetracosane \\
\hline 20 & 57.02 & 0.5515 & methyl 2,7,13 - abietatrienoate \\
\hline 21 & 57.08 & 0.3106 & Octadecane \\
\hline 22 & 57.8 & 0.3232 & Tricontamethylcyclopentadecasiloxane \\
\hline 23 & 57.97 & 0.1247 & Eicosane \\
\hline 24 & 58.76 & 0.2048 & Eicosane \\
\hline 25 & 59.48 & 2.7469 & (Z)-9-Octadecenamide \\
\hline 26 & 60.1 & 0.2388 & Tetracosamethyl-cyclododecasiloxane \\
\hline 27 & 65.36 & 2.3188 & 33 -Ergost-5-en-3-ol \\
\hline 28 & 67.21 & 7.8082 & gamma Sitosterol \\
\hline 29 & 68.15 & 0.4482 & (24R)-Ergost-4-en-3-one \\
\hline 30 & 70.49 & 1.37 & Stigmast-4-en-3-one \\
\hline & & &
\end{tabular}

Table 1. Gas Chromatography analysis of CLOE.

inflammation leading to neoplastic transformation and progression of malignancies ${ }^{12}$. During an inflammatory response, the pro-inflammatory biomarkers are excessively produced such as the reactive oxygen species (ROS), reactive nitrogen species (RNS), tumor necrosis factor- $\alpha$ (TNF- $\alpha$ ) and $\mathrm{PGE}_{2}{ }^{13}$. In this context, the RNS such as nitric oxide (NO) is formed from inducible nitric oxide synthase (iNOS) ${ }^{14}$ and $\mathrm{PGE}_{2}$ is produced from arachidonic acid metabolites by COX-2 ${ }^{15}$. $\mathrm{PGE}_{2}$ has been shown to enhance abnormal cell division, decrease apoptosis, increase angiogenesis, and promote tumor invasiveness and metastasis ${ }^{16}$. Other studies indicated that the overexpression of COX-2 is highly associated with the development of numerous types of epithelial cell-derived cancers including breast, skin, colon, lung, and prostate ${ }^{17}$. Furthermore, inhibition of inducible COX- ${ }^{18}$ by non-steroidal anti-inflammatory drugs caused a decrease in angiogenesis, consequently their use can lead to inhibition of tumor progression and metastasis ${ }^{19}$. Generally, steroids and non-steroidal anti-inflammatory drugs are considered effective medications for prevention of ischemic events and treatment of pain, fever and inflammation. However, these drugs are associated with a significant risk of developing gastrointestinal or cardiovascular complications ${ }^{20}$. Therefore, the selective targeting of COX-2 activity or expression is of considerable clinical importance.

Preliminary studies in our lab demonstrated that $C$. libani wood oil exhibited potent anticancer activity against several human cancer cell lines. Analysis of the crude oil revealed that 2-himachalene-7-ol (himachalol; 7-HC) is a major constituent amounting to around $40 \%$ of the extract. The present study aims to isolate $7-\mathrm{HC}$ and investigate its anticancer activity on various cancer cell lines as well as assess its in vivo and in vitro anti-inflammatory properties.

\section{Results}

Extraction and characterization of 2-himachelen-7-ol. C. libani wood was extracted using warm hexane to yield C. libani Oil Extract, CLOE) as a dark oil (1.95\% yield). GCMS analysis of CLOE (Table 1) identified 30 compounds constituting around $83 \%$ of the oil extract with the remaining $17 \%$ constituting several unidentified compounds whereby none were found to be present in excess of $2 \%$. Notably however, 7 -HC (Fig. 1) was shown to be present at a staggering concentration of $40 \%$ of CLOE. In an attempt to isolate 7 -HC, the oil was then subjected to silica-gel based column chromatography whereby three fractions (F1, F2 and F3) were obtained using a gradient mobile phase of hexane:ethyl acetate. 7-HC was eluted in F2 using 8:2 hexane:ethyl acetate as shown via TLC in which plates were stained with anisaldehyde and the sesquiterpene appeared as a pink spot with an $R f$ value of 0.78 . The sesquiterpene was then recrystallized by adding acetonitrile to the $\mathrm{F} 2$ fraction to 

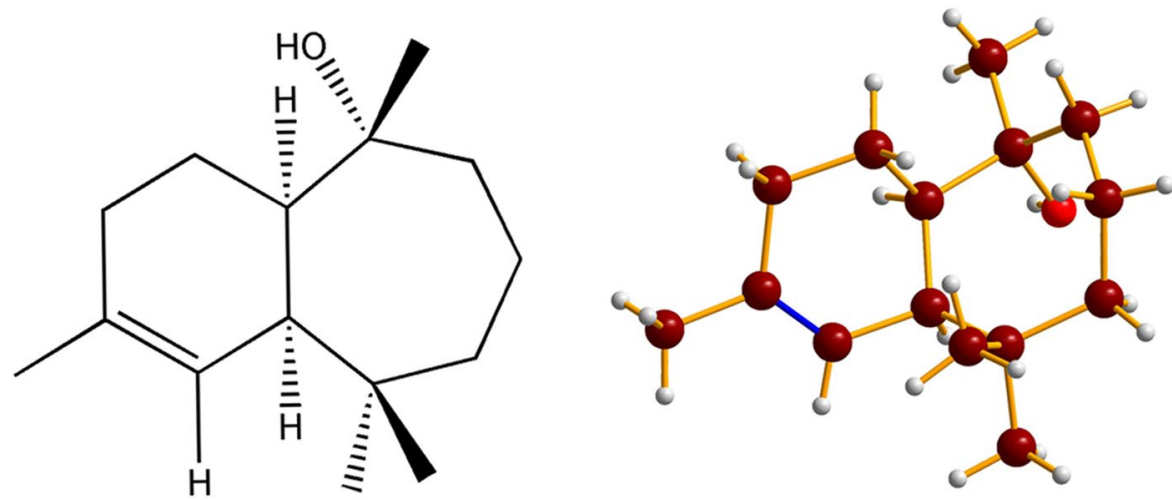

Figure 1. Structure and X-ray crystal structure of 7-HC.
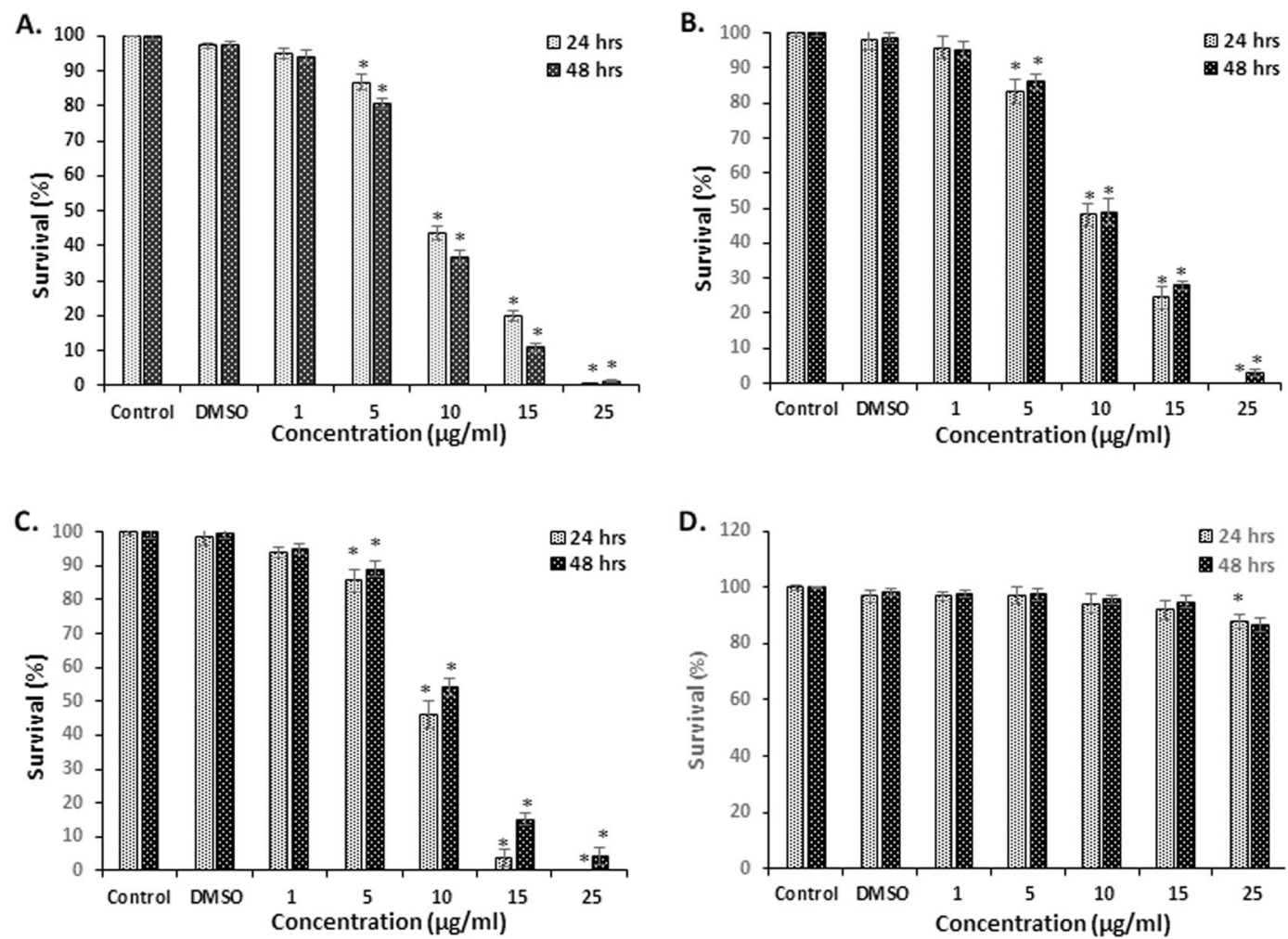

Figure 2. Cytotoxic effect of 7-HC on cell survival. SF-268 (A), Caco-2 (B), HT-29 (C) and Sk-OV-3 (D) cells were subjected to treatment with several concentrations of 7-HC over 24 and $48 \mathrm{~h}$. Data are presented as mean \pm SEM from 3 experiments. *Denotes $\mathrm{P}<0.05$ vs. DMSO group.

yield 7-HC as a white crystalline solid (97\% purity; Fig. 1). The identity and structure of the major compound was confirmed as 2-himachelene-7-ol via GCMS analysis using the NIST11 and Wiley9 mass-spectral database and via ${ }^{13} \mathrm{C}$ NMR spectroscopy (Supplementary Figs S1-S7).

Dose-dependent in vitro cytotoxicity of 7-HC. The cytotoxic effect of 7-HC was examined on several human cancer cell lines. Results showed (Fig. 2) a dose-dependent decrease in cell survival in SF-268, HT-29 and Caco- 2 cell lines with almost complete inhibition of proliferation at $25 \mu \mathrm{g} / \mathrm{mL}$. The $\mathrm{IC}_{50}$ values of $7-\mathrm{HC}$ and Cisplatin in all four cancer cell lines are presented in Table 2. Comparable $\mathrm{IC}_{50}$ values of 7-HC and Cisplatin were observed for SF-268 and Caco-2 cells. However, while HT-29 displayed resistance to Cisplatin, 7-HC was 8-10 folds more potent with an $\mathrm{IC}_{50}$ of 9.1-10.1 $\mu \mathrm{g} / \mathrm{mL}$. Sk-OV-3 cells were the most resistant to treatment with an $\mathrm{IC}_{50}$ value $>50 \mu \mathrm{g} / \mathrm{mL}$.

Synergistic effect of Cisplatin and 7-HC co-treatment. The effect of the co-treatment of 7-HC and Cisplatin on the four cell lines for 24 and $48 \mathrm{~h}$ was examined (Table 3). Results suggest that co-treatment of 


\begin{tabular}{|l|l|l|l|l|l|l|l|l|}
\hline & \multicolumn{9}{|l|}{ Duration } & \multicolumn{3}{l|}{ Cell Lines } \\
\cline { 2 - 9 } & SF-268 & \multicolumn{3}{|l|}{ Caco-2 } & HT-29 & \multicolumn{2}{l|}{ Sk-OV-3 } \\
\cline { 2 - 9 } & 7-HC & Cis & 7-HC & Cis & 7-HC & Cis & 7-HC & Cis \\
\hline $24 \mathrm{~h}$ & $9.2 \pm 0.21$ & $13.9 \pm 0.76$ & $9.6 \pm 1.40$ & $16.7 \pm 2.29$ & $9.1 \pm 0.38$ & $>100$ & $>50$ & $>100$ \\
\hline $48 \mathrm{~h}$ & $8.1 \pm 0.29$ & $5.9 \pm 0.32$ & $9.9 \pm 0.45$ & $9.3 \pm 0.21$ & $10.1 \pm 0.36$ & $78.8 \pm 5.68$ & $>50$ & $>100$ \\
\hline
\end{tabular}

Table 2. $\mathrm{IC}_{50}(\mu \mathrm{g} / \mathrm{mL})$ values of $7-\mathrm{HC}$ and Cisplatin against different human cancer cell lines.

\begin{tabular}{|c|c|c|c|c|c|c|c|c|}
\hline & \multicolumn{4}{|c|}{ Treatment $(\mu \mathrm{g} / \mathrm{ml})$} & \multicolumn{4}{|c|}{ Cell Lines (\% survival) } \\
\hline & \multicolumn{2}{|l|}{ SF-268 } & \multicolumn{2}{|l|}{ Caco-2 } & \multicolumn{2}{|l|}{ HT-29 } & \multicolumn{2}{|l|}{ Sk-OV-3 } \\
\hline & $24 \mathrm{~h}$ & $48 \mathrm{~h}$ & $24 \mathrm{~h}$ & $48 \mathrm{~h}$ & $24 \mathrm{~h}$ & $48 \mathrm{~h}$ & $24 \mathrm{~h}$ & $48 \mathrm{~h}$ \\
\hline Cis (2.5) & $90.1 \pm 4.6$ & $73.0 \pm 1.5$ & $89.8 \pm 4.4$ & $87.9 \pm 3.1$ & $92.6 \pm 3.6$ & $89.7 \pm 2.8$ & $97.9 \pm 1.9$ & $93.7 \pm 1.7$ \\
\hline Cis (5) & $79.0 \pm 4.8$ & $61.7 \pm 3.3$ & $68.3 \pm 1.9$ & $50.1 \pm 2.9$ & $88.9 \pm 3.4$ & $88.7 \pm 2.3$ & $95.6 \pm 2.2$ & $91.7 \pm 1.8$ \\
\hline 7-HC (5) & $86.2 \pm 2.9$ & $80.1 \pm 2.1$ & $85.1 \pm 4.1$ & $87.3 \pm 3.2$ & $86.8 \pm 3.7$ & $89.6 \pm 2.7$ & $97.2 \pm 2.8$ & $99.1 \pm 2.5$ \\
\hline 7-HC (10) & $43.7 \pm 2.5$ & $36.8 \pm 2.4$ & $49.7 \pm 3.8$ & $49.2 \pm 3.4$ & $46.5 \pm 4.1$ & $54.3 \pm 3.0$ & $97.4 \pm 3.2$ & $97.3 \pm 2.3$ \\
\hline Cis (2.5) + 7-HC (5) & $81.4 \pm 2.4$ & $57.3 \pm 1.8^{\mathrm{a}, \mathrm{b}}$ & $78.4 \pm 2.1$ & $74.6 \pm 3.9$ & $79.9 \pm 2.5$ & $82.2 \pm 3.9$ & $95.6 \pm 1.5$ & $89.4 \pm 3.2$ \\
\hline Cis $(2.5)+7-\mathrm{HC}(10)$ & $35.3 \pm 2.3^{\mathrm{a}}$ & $12.4 \pm 3.9^{\mathrm{a}, \mathrm{b}}$ & $41.2 \pm 2.5^{\mathrm{a}}$ & $36.4 \pm 2.8^{\mathrm{a}}$ & $35.6 \pm 3.9^{\mathrm{a}}$ & $44.1 \pm 2.8^{\mathrm{a}, \mathrm{b}}$ & $93.9 \pm 2.5$ & $88.4 \pm 4.1$ \\
\hline Cis (5) + 7-HC (5) & $66.3 \pm 3.2^{\mathrm{a}, \mathrm{b}}$ & $44.1 \pm 2.9^{\mathrm{a}, \mathrm{b}}$ & $59.3 \pm 4.3^{\mathrm{b}}$ & $50.9 \pm 3.1^{\mathrm{b}}$ & $76.2 \pm 2.8^{\mathrm{a}}$ & $78.9 \pm 3.8$ & $94.0 \pm 1.8$ & $86.7 \pm 2.6$ \\
\hline Cis (5) + 7-HC (10) & $26.7 \pm 1.9^{\mathrm{a}, \mathrm{b}}$ & $7.7 \pm 1.3^{\mathrm{a}, \mathrm{b}}$ & $27.1 \pm 2.6^{\mathrm{a}, \mathrm{b}}$ & $23.4 \pm 3.9^{\mathrm{a}, \mathrm{b}}$ & $36.6 \pm 2.2^{\mathrm{a}}$ & $40.1 \pm 3.5^{\mathrm{a}, \mathrm{b}}$ & $92.8 \pm 2.7$ & $87.7 \pm 2.8$ \\
\hline
\end{tabular}

Table 3. Effect of 7-HC, Cisplatin and their combination on human cancer cell survival. The values are expressed as mean \pm SEM from three independent experiments. Means with superscripts ${ }^{\left({ }^{\prime}\right)}$ and/or ${ }^{\text {(b) }}$ are significantly $(\mathrm{p}<0.05)$ different compared to similar doses of Cisplatin and/or 7-HC respectively.

\begin{tabular}{|l|l|l|l|l|}
\hline \multicolumn{5}{|l|}{ Combination Index (CI) } \\
\hline Treatment $(\boldsymbol{\mu g} / \mathbf{m l})$ & SF-268 48 h & Caco-2 48 h & HT-29 48 h & Sk-OV-3 48h \\
\hline Combo 1: Cis (2.5)+ 7-HC (5) & 1.63 & 1.79 & 1.87 & 0.32 \\
\hline Combo 2: Cis (2.5)+7-HC (10) & 0.81 & 1.18 & 1.19 & 0.31 \\
\hline Combo 3: Cis (5)+7-HC (5) & 1.59 & 1.23 & 1.87 & 0.39 \\
\hline Combo 4: Cis (5)+7-HC (10) & 0.68 & 0.96 & 1.12 & 0.52 \\
\hline
\end{tabular}

Table 4. Combination index of 7-HC and cisplatin treatment.

Cisplatin and 7-HC at the highest concentrations $(5$ and $10 \mu \mathrm{g} / \mathrm{mL}$ respectively) exerted a significant synergistic cytotoxic effect on SF-268, Caco-2 and HT-29 cells as compared to a single treatment of each drug (Tables 4,5). SF-268 cells were found to be the most sensitive to this combined treatment. The synergistic inhibitory effect of both drugs was not observed on Sk-OV-3 cells.

Inhibition of chronic inflammation in rats. 7-HC significantly inhibited the chronic inflammation in rats at all concentrations used in a non-dose dependent manner (Table 6). A $100 \mathrm{mg} / \mathrm{kg}$ dose of 7-HC showed comparable effects to Diclophenac $(10 \mathrm{mg} / \mathrm{kg})$ with $63.1 \%$ paw edema inhibition. The effect of increasing concentrations of 7-HC on the level of protein expression of COX-2 in LPS-activated rat peripheral blood mononuclear cells (PBMC) was investigated. Western blot analysis (Fig. 3; cropped Western Blots) demonstrated that 7-HC markedly inhibits the expression of COX-2 compared with the control group (for the full Western Blots please refer to Supplementary Figs S8, S9). Significant suppression of COX-2 protein induction was observed at concentrations of 25 and $50 \mu \mathrm{g} / \mathrm{mL}$.

Activity of 7-HC against rat monocytes. The cytotoxic effect of 7-HC using WST (Fig. 4) was tested on isolated monocytes after $6 \mathrm{~h}$ of treatment. The results revealed that 2-himachalene-7-ol causes only 7.7\%, 11.5\% and $12.7 \%$ reduction in cell survival at concentrations of $10 \mu \mathrm{g} / \mathrm{mL}, 25 \mu \mathrm{g} / \mathrm{mL}$ and $50 \mu \mathrm{g} / \mathrm{mL}$, respectively.

\section{Discussion}

Phytochemical analysis of the CLOE revealed that sesquiterpenes are the main constituents with 7-HC (40\%), $\alpha$-himachalene (2.96\%), $\beta$-himachalene (3.18\%) and $\gamma$-himachalene (3.37\%) being the major components. A comparable qualitative composition of the aforementioned sesquiterpenes was previously reported in the Lebanese cedar wood oil ${ }^{21}$. However, in the present study, the percentage composition of $\alpha$-himachalene, $\beta$-himachalene and $\gamma$-himachalene present in CLOE was lower than that of heartwood oil previously reported ${ }^{21}$. This quantitative difference may be attributed to factors such as geographical location, humidity, altitude level, collection period, extraction technique and plant age.

In the present study, we have optimized a chromatographic procedure which enables the isolation of 7 - $\mathrm{HC}$ from CLOE in excess of $97 \%$ purity. The purified sesquiterpene was then evaluated for its in vitro cytotoxic effects 


\section{Values at Various Fa (Fa represents \% Inhibition/100)}

\begin{tabular}{|c|c|c|c|c|c|c|c|c|c|c|c|c|c|c|c|c|c|c|c|c|}
\hline $\mathrm{Fa}$ & 0.05 & 0.1 & 0.15 & 0.2 & 0.25 & 0.3 & 0.35 & 0.4 & 0.45 & 0.5 & 0.55 & 0.6 & 0.65 & 0.7 & 0.75 & 0.8 & 0.85 & \begin{tabular}{|l|}
0.9 \\
\end{tabular} & 0.95 & 0.97 \\
\hline SF-268 & 4.5 & 3.3 & 2.8 & 2.4 & 2.2 & 2.0 & 1.8 & 1.7 & 1.6 & 1.5 & 1.4 & 1.3 & 1.2 & 1.1 & 1.0 & 0.9 & 0.8 & 0.7 & 0.6 & 0.5 \\
\hline Caco-2 & 3.1 & 2.5 & 2.2 & 2.0 & 1.8 & 1.7 & 1.6 & 1.5 & 1.4 & 1.3 & 1.2 & 1.2 & 1.1 & 1.0 & 0.9 & 0.9 & 0.8 & \begin{tabular}{|l|l|}
0.7 & \\
\end{tabular} & 0.6 & 0.5 \\
\hline HT-29 & 3.7 & 2.5 & 2.0 & 1.8 & 1.6 & 1.5 & 1.4 & 1.3 & 1.3 & 1.2 & 1.2 & 1.1 & 1.1 & 1.0 & 0.9 & 0.9 & 0.9 & 0.8 & 0.7 & 0.6 \\
\hline SK-OV-3 & 0.04 & 0.3 & 0.9 & 2.5 & 5.6 & 11 & 21 & 40 & 73 & $99+$ & $99+$ & $99+$ & $99+$ & $99+$ & $99+$ & $99+$ & $99+$ & $99+$ & $99+$ & $99+$ \\
\hline
\end{tabular}

Table 5. Extrapolated CI values at various inhibitory effects.

\begin{tabular}{|l|l|l|}
\hline Group & Change in paw thickness & \% Inhibition \\
\hline Control (DMSO) & $1.25 \pm 0.112$ & $0 \%$ \\
\hline Diclophenac $(10 \mathrm{mg} / \mathrm{kg})$ & $0.498 \pm 0.067^{* *}$ & $60.2 \%$ \\
\hline 7-HC $(10 \mathrm{mg} / \mathrm{kg})$ & $0.740 \pm 0.051^{* *}$ & $40.9 \%$ \\
\hline $7-\mathrm{HC}(25 \mathrm{mg} / \mathrm{kg})$ & $0.760 \pm 0.123^{* *}$ & $39.3 \%$ \\
\hline 7-HC $(50 \mathrm{mg} / \mathrm{kg})$ & $0.304 \pm 0.075^{*}$ & $75.7 \%$ \\
\hline $7-\mathrm{HC}(100 \mathrm{mg} / \mathrm{kg})$ & $0.462 \pm 0.121^{* *}$ & $63.1 \%$ \\
\hline
\end{tabular}

Table 6. Effect of 7-HC intraperitoneal treatment on formalin-induced chronic inflammation in rats.

*Significant difference $(p<0.05)$ with respect to the control.

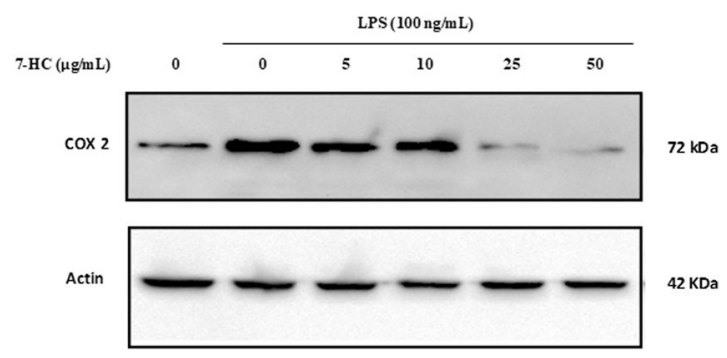

Figure 3. 7-HC blocked LPS-induced COX-2 protein expression in rat monocytes (cropped Western Blots). PMBC were incubated with vehicle control alone, with LPS $(100 \mathrm{ng} / \mathrm{ml})$ alone, or with $5,10,25 \mathrm{or} 50 \mu \mathrm{g} / \mathrm{mL}$ of 7 -HC for $30 \mathrm{~min}$ prior to stimulation with LPS $(100 \mathrm{ng} / \mathrm{mL})$ for $6 \mathrm{~h}(n=3)$.

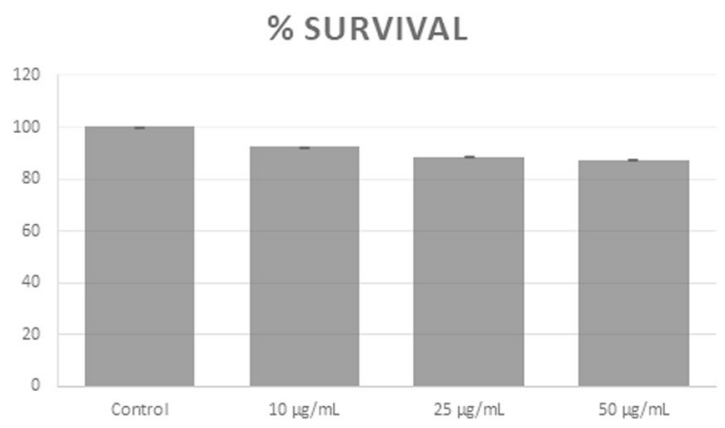

Figure 4. Activity of 7-HC using WST against isolated rat monocytes at $6 \mathrm{~h}$ post-treatment.

against several types of cancer cells as well as its in vivo and in vitro anti-inflammatory activity. The results showed that 7-HC exerts a dose dependent cytotoxicity against all tested cancer cells except for Sk-OV-3, indicating selectivity against certain cancer cell lines. This anticancer effect suggests that the previously reported activity of CLOE against human leukemia cells could be attributed to $7-\mathrm{HC}^{11}$. In addition, earlier work in our lab showed that 3 -2-himachalene-6-ol, an isomer of 7-HC, isolated from wild carrot demonstrated potent anticancer activity against several human and murine cancer cell lines ${ }^{22,23}$. $\beta$-2-Himachalene-6-ol was also found to exhibit significant anti-tumor promoting effect against DMBA/TPA skin carcinogenesis and dimethylhydrazine-induced colon carcinogenesis in mice ${ }^{24}$.

Cisplatin, the most commonly used antineoplastic agent, mediates its anticancer activity through various cytotoxic mechanisms, including DNA damage, activation of apoptotic pathways and inflicting damage to the 
cells through inflammation and oxidative stress ${ }^{25}$. The current results showed that HT-29 cells were resistant to Cisplatin $\left(\mathrm{IC}_{50}>100 \mu \mathrm{g} / \mathrm{mL}\right.$ and $78.78 \mu \mathrm{g} / \mathrm{mL}$ at 24 and $48 \mathrm{~h}$, respectively), while $7-\mathrm{HC}$ exhibited potent dose-dependent anticancer activity $\left(\mathrm{IC}_{50}=9.122 \mu \mathrm{g} / \mathrm{mL}\right.$ and $10.11 \mu \mathrm{g} / \mathrm{mL}$ at 24 and $48 \mathrm{~h}$, respectively). Sk-OV-3 cells, however, were shown to be resistant against both $7-\mathrm{HC}$ and Cisplatin treatment $\left(\mathrm{IC}_{50}>100 \mu \mathrm{g} / \mathrm{mL}\right.$ ). The $\mathrm{IC}_{50}$ values of Cisplatin on the same cancer cell lines are in agreement with the literature ${ }^{26,27}$. In an attempt to achieve an improved therapeutic outcome, all 4 cell lines were subjected to a combination of 7 - $\mathrm{HC}$ and the conventional antineoplastic drug Cisplatin (Table 3). Drug Combination Index (CI) was determined using the commonly used Loewe additivity model and CompuSyn software ${ }^{28}$. Briefly, CI values equal to 1 suggest additivity, values below 1 suggest synergy while values above 1 suggest antagonism ${ }^{28}$. Table 4 shows that the most desired combinations which lead to synergism correspond to Combination 2: Cis (2.5) + 7-HC(10) and Combination 4: $\mathrm{Cis}(5)+7-\mathrm{HC}(10)$. In addition, the Loewe model extrapolates ${ }^{28}$ (Table 5) that synergism would occur with combinations of 7-HC and Cisplatin that lead to 75\% cell inhibition (SF-268, Caco-2 and HT-29) or above. Results reveal that combinations consisting of a high $7-\mathrm{HC}$ concentration $(10 \mu \mathrm{g} / \mathrm{mL})$ and a low Cisplatin concentration $(2.5 \mu \mathrm{g} / \mathrm{mL})$ would induce significant cell inhibition via synergistic pathways. Such a synergistic effect could be exploited in reducing the adverse effects of Cisplatin by eliminating the dose limiting nephrotoxicity while maintaining potency against cancerous cells ${ }^{25}$. Table 4 also shows that all four drug combinations exerted a synergistic effect against the Sk-OV-3 cell line, yet these results are insignificant as cell inhibition via synergism didn't exceed $15 \%$. As the literature reports, synergistic effects are mainly desirable when accompanied with significant cell inhibition as observed with Combinations (2) and (4) against SF-268, Caco-2 and HT-29 cell lines ${ }^{28}$.

A substantial body of evidence obtained from both in vivo and in vitro studies reported that plant-derived extracts containing sesquiterpenes, alkaloids, phenolic compounds and flavonoids demonstrate anti-inflammatory activity by controlling the levels of various inflammatory biomarkers including TNF- $\alpha$, NF- $\kappa B, N O$, iNOS and COX- $2^{29}$. Cyclooxygenase-2 (COX-2) is a key pro-inflammatory enzyme induced by LPS or cytokines, and was found to be implicated in inflammation, malignancies, and angiogenesis ${ }^{30}$. Therefore, identifying a new compound with an inhibitory effect on COX-2 protein is regarded as an important requirement for the treatment of inflammation-related disorders. The results of this study show that 7-HC possesses significant anti-inflammatory activity against chronic inflammation in rats. Several inflammatory mediators such as kinins, prostaglandins, and serotonin may account for the edema formation caused by sub plantar formalin injection $^{31}$. The increased synthesis of prostaglandins could be due to increased release of arachidonic acid from the membrane phospholipids and/or the up-regulation of COX-2. Western blot analysis showed that the production of COX-2 was markedly elevated after LPS treatment of rat monocytes. However, the application of different doses of 7-HC inhibited the protein expression of COX-2 by LPS in a dose dependent manner. Hence, the anti-inflammatory activity of 7-HC is partially mediated through the suppression of COX-2 expression. Previous reports revealed that himachalol, derived from the wood of $C$. deodara displayed substantial anti-allergic activity and has been identified as a major anti-spasmodic constituent ${ }^{32}$. The cytotoxic effect of 7-HC against rat monocytes was shown to be insignificant with $7.7 \%, 11.5 \%$ and $12.7 \%$ reduction in cell survival at concentrations of $10 \mu \mathrm{g} / \mathrm{mL}, 25 \mu \mathrm{g} / \mathrm{mL}$ and $50 \mu \mathrm{g} / \mathrm{mL}$, respectively. This indicates that 7-HC has a minor cytotoxic effect on isolated rat monocytes (at the selected concentrations). This result also supports the selectivity of 2-himachalene-7-ol on cancer cells relative to normal cells.

\section{Conclusion}

C. libani essential oil was extracted and analyzed via GCMS whereby 2-himahcalene-7-ol (7-HC) was found to constitute $40 \%$ of the oil. 7 -HC was isolated using silica-gel column chromatography to afford the sesquiterpenes as a white crystalline solid and $97 \%$ purity. 7-HC demonstrated potent cytotoxic activity against SF-268 (IC ${ }_{50}$ $8.1 \mu \mathrm{g} / \mathrm{mL}), \mathrm{HT}-29\left(\mathrm{IC}_{50} 10.1 \mu \mathrm{g} / \mathrm{mL}\right)$ and Caco-2 $\left(\mathrm{IC}_{50} 9.9 \mu \mathrm{g} / \mathrm{mL}\right)$. In addition, while HT-29 displayed resistance to Cisplatin, 7-HC was 8-10 folds more potent. Co-treatment with combinations of 7-HC:Cisplatin (2:1 and 4:1 ratio) showed a significant synergistic anti-proliferative effect against SF-268, HT-29 and Caco-2 cells. 7-HC also exhibited significant anti-inflammatory effect in formalin-induced paw edema in rats as well as dose dependent inhibition of LPS-induced COX-2 protein expression in isolated rat monocytes. The present study demonstrates that 7-HC possesses promising anticancer and anti-inflammatory activities, and may serve as a lead molecule in cancer therapy.

\section{Materials and Methods}

General experimental procedures. UV spectra were recorded using a Shimadzu UV2450 spectrophotometer. The ${ }^{1} \mathrm{H},{ }^{13} \mathrm{C}$ and 2D NMR spectra were obtained on a Bruker Avanc3-400 MHz NMR spectrometer or Varian Mercury-300 NMR spectrometer using TMS as an internal reference. TLC analysis was carried out on silica gel plates (ACROS organics, New Jersey, USA). Silica gel 60 (230-400 mesh or 70-230 mesh, $47 \mathrm{~cm}$ by $2.5 \mathrm{~cm}$, ACROS organics, New Jersey, USA) was used for column chromatography. GCMS analysis was carried out using Hewlett Packard, HP6890 series, fitted with a fused silica HP5-MS 5\% phenyl methyl siloxane cap column $(30 \mathrm{~m} \times 0.25 \mathrm{~mm}$ i.d., film thickness 0.25$)$ and directly coupled to the MS. The ELIZA microplate reader was purchased from BioTek (Winooski, VT, USA).

Chemicals and reagents. Dulbecco's modified Eagle's medium (DMEM) and dimethyl sulfoxide (DMSO) were purchased from Sigma (St. Louis, Missouri, USA). PVDF membranes were purchased from Pall Corporation (Ann Arbor, MI, USA). Actin and Cox-2 antibodies were purchased from Abcam (Cambridge, MA, USA). HRP-coupled secondary antibodies were purchased from Promega Corporation (Madison, WI, USA). The ECL kit was purchased from Abcam (Milton, Cambridge, UK). Fetal bovine serum (FBS), penicillin-streptomycin, glycine, lysis buffer solution, phosphate buffer saline (PBS), bovine serum albumin (BSA), tris-buffered saline with Tween $20^{\circledR}$ (TBST), HEPES buffer, sodium dodecyl sulfate (SDS), well plates, pentane, diethyl ether, hexane, ethyl 
acetate, anisaldehyde, ethanol, paraformaldehyde, trypan blue, Ficoll (Histopaque-1077). Crystal violet, trypsin, $\mathrm{d}_{6}$-DMSO and $\mathrm{CDCl}_{3}$ were purchased from Sigma (St. Louis, Missouri, USA) unless otherwise stated.

Cedrus libani extraction. Cedar wood was collected from North Lebanon, from mature cedar trees during the month of February when the trees are pruned in order to enhance their growth in the following season. Pieces of pruned wood were collected after acquiring permission from the Municipality of Amioun, El-Koura. The tree was identified according to the characteristics described in the "Medicinal Plants of The World"33. A specimen, (ID 2015-0019) was deposited at the School of Arts and Sciences, Lebanese American University, Lebanon. The wood sample was air dried in the shade, shredded and subjected to hexane extraction $(72 \mathrm{~h})$. The filtered extract was evaporated to dryness under reduced pressure and the remaining oil (CLOE) was dried over anhydrous sodium sulfate (yield 1.95\%) and stored in a closed amber bottle at $4{ }^{\circ} \mathrm{C}$ until use. CLOE ( $5 \mathrm{~g}$ ) was chromatographed on a silica gel column (230-400 mesh) using a gradient mobile phase of hexane/ethyl acetate to collect three fractions $(9: 1,600 \mathrm{~mL}, \mathrm{~F} 1 ; 8: 2,600 \mathrm{~mL}, \mathrm{~F} 2 ; 7: 3,500+\mathrm{mL}, \mathrm{F} 3)$. Fractions were analyzed by TLC using hexane:ethyl acetate (8:2) as mobile phase and plates were stained with $2 \%$ anisaldehyde in which 2-himachelen-7-ol appeared as a pink spot with an $R f$ value of 0.78 . F2 $(1.8 \mathrm{~g})$ was then mixed with acetonitrile and stored for 3 days in the freezer to recrystallize 2-himachelen-7-ol as a white crystalline solid (1.2 g, 97\% purity). ${ }^{13} \mathrm{C} \mathrm{NMR} 75 \mathrm{MHz}$ in $\mathrm{CDCl}_{3}: \delta 133.4,125.6,76.2,51.9,43.6,41.4,38.4,36.4,33.5,32.7,31.7,26.7,23.6,22.3$ and $19.9 \mathrm{ppm}$.

Gas Chromatography and Mass Spectrometry (GC-MS) analysis. CLOE, fractions and 7-HC were analyzed via GC-MS using helium as the carrier gas with splitless injection and a flow rate of $1.2 \mathrm{~mL} / \mathrm{min}$. The temperature program was $2.0 \mathrm{~min}$ at $70^{\circ} \mathrm{C}$, from 70 to $130^{\circ} \mathrm{C}$ at $8^{\circ} \mathrm{C} / \mathrm{min}$ and hold for $5 \mathrm{~min}$, from 130 to $180^{\circ} \mathrm{C}$ at $2^{\circ} \mathrm{C} / \mathrm{min}$ and hold for $10 \mathrm{~min}$, from 180 to $220^{\circ} \mathrm{C}$ at $15^{\circ} \mathrm{C} / \mathrm{min}$ and hold for $2 \mathrm{~min}$ and then from 220 to $280^{\circ} \mathrm{C}$ at $15^{\circ} \mathrm{C} / \mathrm{min}$ and hold for $22 \mathrm{~min}$. Preliminary identification of all compounds was performed by comparing their mass spectra with the literature (NIST11 and Wiley9). Percentage composition was computed from GC peak areas. GC-MS: $\mathrm{CHCl}_{3} \mathrm{~m} / z$ : 222.2 (1), 204.2 (46), 189.2 (17), 175.1 (4), 161.1 (20), 147.1 (16), 133.1 (34), 119.1 (100), $105.1(44), 91.1(41), 77.1(21), 69.1(15)$ and $55.1(16)$.

Cell survival assay. Four human cancer cell lines were used in this study: SF-268 (human astrocytoma cell line), Caco-2 (human colon cancer cell line), HT-29 (human colon cancer cell line), and Sk-OV-3 (human ovarian cancer cell line). SF-268, Sk-OV-3 were grown in Dulbecco's modified Eagle's medium (DMEM), while Caco-2 and HT-29 were maintained in Roswell Park Memorial Institute Medium (RPMI). Both media contained 10\% Fetal Bovine Serum (FBS) and $100 \mu \mathrm{g} / \mathrm{mL}$ streptomycin and $100 \mathrm{U} / \mathrm{mL}$ penicillin. All cell lines were incubated in a humidified chamber at $37^{\circ} \mathrm{C}$ and $5 \% \mathrm{CO}_{2}$. Cells $\left(1 \times 10^{4} \mathrm{cell} / \mathrm{mL}\right)$ were plated in 96 -well plates for $24 \mathrm{~h}$ and then treated with either $7-\mathrm{HC}$ in DMSO $(1,5,10,15$ and $25 \mu \mathrm{g} / \mathrm{mL})$ or cisplatin for $24 \mathrm{~h}$ and $48 \mathrm{~h}$. In addition, the concomitant treatment of $7-\mathrm{HC}(2.5$ and $5 \mu \mathrm{g} / \mathrm{mL})$ and Cisplatin $(5$ and $10 \mu \mathrm{g} / \mathrm{mL})$ was carried out. Cell viability was measured using WST-1 (Roche Diagnostics, Indianapolis, IN, USA). Absorbance was measured at $450 \mathrm{~nm}$ using Multiskan FC microplate ELISA reader (Thermo fisher Scientific, Rockford, IL, USA). Cells were plated in duplicates, and experiments were repeated three times.

Monocytes isolation and stimulation. The experiment was conducted in accordance with the internationally accepted principles set by the Office of Laboratory Animal Welfare (NIH, PHS Policy on Human Care and Use of Laboratory Animals, USA 2015) and approved by the Animal Ethical Committee at the Lebanese American University. Isolation of fresh peripheral blood mononuclear cells (PBMCs), consisting of monocytes and lymphocytes, was performed as previously described ${ }^{26}$ from blood samples of healthy young male Sprague Dawley rats of (6 weeks age; weighing $250 \mathrm{~g}$ ) and pretreated with EDTA. EDTA-treated blood (4 mM) was diluted with an equal sterile volume of warm PBS, and centrifuged over Ficoll. The buffy coat that formed at the interface and containing most of the monocytes cells is carefully removed with a sterile pipet and transferred into a sterile $50 \mathrm{ml}$ conical tube and washed twice with sterile warm PBS by centrifugation. Cells were then seeded in $2 \mathrm{~mL}$ RPMI medium supplemented with FBS $(10 \%)$, penicillin $(100 \mathrm{U} / \mathrm{mL})$ and streptomycin $(100 \mu \mathrm{g} / \mathrm{mL})$ in six-well culture plates $\left(4 \times 10^{5} \mathrm{cells} / \mathrm{cm}^{2}\right)$ and allowed to adhere overnight $\left(37^{\circ} \mathrm{C} ; 5 \% \mathrm{CO}_{2}\right)$. The non-adherent cells (mainly lymphocytes) were removed by vigorous washing with warm sterile PBS (three times). The obtained monocytes/macrophages exceeded $95 \%$ purity. Trypan blue exclusion was used to determine cell viability. Trypan blue exclusion was used to determine cell viability. Monocytes were cultured in RPMI-free media in a total volume of $2 \mathrm{~mL}$ for $6 \mathrm{~h}$ in six-well plates in the presence or absence of bacterial LPS $(100 \mathrm{ng} / \mathrm{mL})$ and increasing concentrations of $7-\mathrm{HC}(5,10,25,50 \mu \mathrm{g} / \mathrm{mL}) .7-\mathrm{HC}$ was added $30 \mathrm{~min}$ before stimulation with LPS.

Western blot analysis. PBMCs were collected on ice, washed with PBS, lysed with lysis buffer and centrifuged at $12,000 \mathrm{~g}$ for $10 \mathrm{~min}$ at $4^{\circ} \mathrm{C}$. The cell lysate was heated at $100^{\circ} \mathrm{C}$ for $5 \mathrm{~min}$, and the protein content was determined using the Bio-Rad protein assay (Bio-Rad, Hercules, CA, USA). Equal concentrations of the proteins were loaded to $10 \%$ SDS-PAGE and then transferred to PVDF membrane (Pall Corporation, Ann Arbor, USA) and blocked with blocking buffer $(1 \times$ TBS, $0.1 \%$ Tween-20, $5 \%$ skim milk) for $2 \mathrm{~h}$. The membranes were then probed with primary antibodies against Actin and $\mathrm{Cox}-2$ at $4{ }^{\circ} \mathrm{C}$ overnight. The primary antibodies were then washed away with TBST for $2 \mathrm{~h}$ and the membranes were treated with horseradish peroxidase (HRP)-coupled secondary antibodies for $1 \mathrm{~h}$, and washed with TBST afterwards. Protein detection was performed using the chemiluminescence ECL kit. Finally, blot images were then obtained with the image lab Software (BioRad, Chemidoc imaging instrument).

Monocytes cell survival assay. Rat monocytes were plated in 12-well plates in RPMI medium supplemented with FBS $(10 \%)$, penicillin $(100 \mathrm{U} / \mathrm{mL})$ and streptomycin $(100 \mu \mathrm{g} / \mathrm{mL})$ and allowed to adhere overnight 
$\left(37^{\circ} \mathrm{C} ; 5 \% \mathrm{CO}_{2}\right)$ for $24 \mathrm{~h}$. Cells were then treated with increasing concentrations of $7-\mathrm{HC}(10,25$ and $50 \mu \mathrm{g} / \mathrm{mL})$ for $6 \mathrm{~h}$. Cell viability was measured using WST-1 (Roche Diagnostics, Indianapolis, IN, USA). Absorbance was measured at $450 \mathrm{~nm}$ using Multiskan FC microplate ELISA reader (Thermo fisher Scientific, Rockford, IL, USA). Cells were plated in duplicates, and experiments were repeated three times.

Formalin induced paw edema. Sprague Dawley rats were divided into six groups of six animals each. In all groups, chronic inflammation was produced by a subplantar injection of $20 \mu \mathrm{L}$ of $2 \%$ formalin in the right hind $\mathrm{paw}^{34}$. Thirty min prior to formalin injection, four groups received 7-HC (i.p.) in saline at a concentration of $10,25,50$, or $100 \mathrm{mg} / \mathrm{kg} \mathrm{BW}$, one group received the standard reference drug diclofenac ( $10 \mathrm{mg} / \mathrm{Kg} \mathrm{BW}$, i.p.), and one group served as a negative control. The administration of 7-HC and diclofenac was continued once daily for 6 consecutive days. The paw thickness was measured using a Vernier caliper before and 6 days after formalin injection ${ }^{31}$. The increase in paw thickness was calculated using the formula: $\left[\mathrm{P}_{t}-\mathrm{P}_{0}\right]$; where $\mathrm{P}_{\mathrm{t}}$ is the thickness of paw at 6 days after formalin injection and $\mathrm{P}_{0}$ is the paw thickness at time 0 . The percent inhibition was calculated using the formula: $[(\mathrm{C}-\mathrm{T}) / \mathrm{C} \times 100]$; where $C$ is the increase in paw thickness of the positive control and $T$ is that of treatments.

Statistical analysis. The results were analyzed for statistical significance using one way analysis of variance (ANOVA). Values of the different tested parameters within each group are presented as mean \pm SEM. All data were analyzed with the statistical package SPSS 18, and differences between groups were considered statistically significant if p-value $<0.05$. The $\mathrm{IC}_{50}$ values were calculated using the nonlinear regression curve with the use of Graph Pad Prism version 5.0 software for Windows.

\section{Data Availability}

The authors declare that the manuscript contains the minimal dataset that is required to interpret, replicate and build upon the methods and findings reported in the article.

\section{References}

1. Ouhtit, A. et al. Simultaneous inhibition of cell-cycle, proliferation, survival, metastatic pathways and induction of apoptosis in breast cancer cells by a phytochemical super-cocktail: Genes that underpin its mode of action. Journal of Cancer 4, 703-715, https:// doi.org/10.7150/jca.7235 (2014).

2. Sak, K., Jürisoo, K. \& Raal, A. Estonian folk traditional experiences on natural anticancer remedies: From past to the future. Pharmaceutical Biology 52, 855-866, https://doi.org/10.3109/13880209.2013.871641 (2014).

3. Panetsos, K., Christou, A. \& Scaltsoyiannes, A. First analysis on allozyme variation in cedar species (Cedrus sp.). Silvae Genetica 41, 339-342 (1992).

4. Reddy, S. E., Kirti Dolma, S., Koundal, R. \& Singh, B. Chemical composition and insecticidal activities of essential oils against diamondback moth, Plutella xylostella (L.) (Lepidoptera: Yponomeutidae). Natural product research 30, 1834-1838 (2016).

5. Barrero, A. F. et al. Abietane diterpenes from the cones of Cedrus atlantica. Phytochemistry 66, 105-111 (2005).

6. Derwich, E., Benziane, Z. \& Boukir, A. Chemical composition and in vitro antibacterial activity of the essential oil of Cedrus atlantica. Int. J. Agric. Biol 12, 381-385 (2010).

7. Singh, S. K. et al. Chemically standardized isolates from Cedrus deodara stem wood having anticancer activity. Planta medica 73 , 519-526 (2007)

8. Shinde, U. et al. Membrane stabilizing activity-a possible mechanism of action for the anti-inflammatory activity of Cedrus deodara wood oil. Fitoterapia 70, 251-257 (1999).

9. Dakir, M. et al. Antibacterial diterpenoids from Cedrus atlantica. Natural product research 19, 719-722 (2005).

10. Guerrini, A. Antiproliferative and erythroid differentiation activities of Cedrus libani seed extracts against K562 human chronic myelogenus leukemia cells. International Journal of Pharmaceutical \& Biological Archive 2 (2011).

11. Saab, A. M. et al. Phytochemical analysis and cytotoxicity towards multidrug-resistant leukemia cells of essential oils derived from lebanese medicinal plants. Planta Medica 78, 1927-1931, https://doi.org/10.1055/s-0032-1327896 (2012).

12. Piazza, G. A. et al. NSAIDs: old drugs reveal new anticancer targets. Pharmaceuticals 3, 1652-1667 (2010),

13. Zha, S., Yegnasubramanian, V., Nelson, W. G., Isaacs, W. B. \& De Marzo, A. M. Cyclooxygenases in cancer: progress and perspective. Cancer Lett. 215, 1-20 (2004).

14. Salvemini, D. \& Marino, M. H. Inducible nitric oxide synthase and inflammation. Expert opinion on investigational drugs 7, 65-75 (1998).

15. Harris, R. E., Beebe-Donk, J. \& Schuller, H. M. Chemoprevention of lung cancer by non-steroidal anti-inflammatory drugs among cigarette smokers. Oncology reports 9, 693-696 (2002).

16. Greenhough, A. et al. The COX-2/PGE2 pathway: key roles in the hallmarks of cancer and adaptation to the tumour microenvironment. Carcinogenesis 30, 377-386 (2009).

17. Shim, J. Y. et al. Overexpression of cyclooxygenase-2 is associated with breast carcinoma and its poor prognostic factors. Modern pathology 16, 1199-1204 (2003).

18. Yuan, C. et al. Cyclooxygenase allosterism, fatty acid-mediated cross-talk between monomers of cyclooxygenase homodimers. Journal of Biological Chemistry 284, 10046-10055 (2009).

19. Umar, A., Steele, V. E., Menter, D. G. \& Hawk, E. T. Mechanisms of nonsteroidal anti-inflammatory drugs in cancer prevention. Seminars in Oncology 43, 65-77, https://doi.org/10.1053/j.seminoncol.2015.09.010 (2016).

20. Vonkeman, H. E. \& van de Laar, M. A. In Semin. Arthritis Rheum. 294-312 (Elsevier).

21. Saab, A. M., Harb, F. Y. \& Koenig, W. A. Essential oil components in heart wood of Cedrus libani and Cedrus atlantica from Lebanon. Minerva Biotecnologica 17, 159-161 (2005).

22. Taleb, R. I. et al. $\beta$-2-himachalen-6-ol: A novel anticancer sesquiterpene unique to the Lebanese wild carrot. Journal of ethnopharmacology 190, 59-67 (2016).

23. Daaboul, H. E. et al. Antitumor activity of $\beta$-2-himachalen-6-ol in colon cancer is mediated through its inhibition of the PI3K and MAPK pathways. Chemico-Biological Interactions 275, 162-170, https://doi.org/10.1016/j.cbi.2017.08.003 (2017).

24. Daaboul, H. E. et al. $\beta$-2-himachalen-6-ol protects against skin cancer development in vitro and in vivo. Journal of Pharmacy and Pharmacology 69, 1552-1564, https://doi.org/10.1111/jphp.12796 (2017).

25. Manohar, S. \& Leung, N. Cisplatin nephrotoxicity: a review of the literature. Journal of nephrology 31, 15-25 (2018).

26. Abd El Razik, H. A. et al. Synthesis of new pyrazolo $[3,4-\mathrm{d}]$ pyrimidine derivatives and evaluation of their anti-inflammatory and anticancer activities. Chemical biology \& drug design 90, 83-96 (2017). 
27. Rone, A. et al. Human topoisomerase inhibition and DNA/BSA binding of Ru (II)-SCAR complexes as potential anticancer candidates for oral application. BioMetals 30, 321-334 (2017).

28. Huang, L., Jiang, Y. \& Chen, Y. Predicting Drug Combination Index and Simulating the Network-Regulation Dynamics by Mathematical Modeling of Drug-Targeted EGFR-ERK Signaling Pathway. Scientific Reports 7, 40752, https://doi.org/10.1038/ srep40752, https://www.nature.com/articles/srep40752\#supplementary-information (2017).

29. Wei, W.-C. et al. Anti-inflammatory activities of natural products isolated from soft corals of Taiwan between 2008 and 2012. Marine drugs 11, 4083-4126 (2013).

30. Regulski, M. et al. COX-2 inhibitors: a novel strategy in the management of breast cancer. Drug discovery today 21, 598-615 (2016).

31. Jose, N., Ajith, T. \& Janardhanan, K. Methanol extract of the oyster mushroom, Pleurotus florida, inhibits inflammation and platelet aggregation. Phytotherapy Research: An International Journal Devoted to Pharmacological and Toxicological Evaluation of Natural Product Derivatives 18, 43-46 (2004).

32. Gupta, P., Kulshrestha, D. \& Patnaik, G. Antiallergic activity of Cedrus deodara. J Med Aromatic Plant Sci 19, 1007-1008 (1997).

33. Van Wyk, B.-E. \& Wink, M. Medicinal plants of the world: an illustrated scientific guide to important medicinal plants and their uses. 1 edn, 124 (Briza Publications, 2004).

34. Ajith, T. \& Janardhanan, K. Antioxidant and anti-inflammatory activities of methanol extract of Phellinus rimosus (Berk) Pilat. (2001).

\section{Acknowledgements}

We thank the School of Arts and Sciences and School of Pharmacy at the Lebanese American University for providing the funding and facilities to carry out the analysis described in this manuscript. Special thanks go to Mr. Jean Karam who helped with the in vivo experiments.

\section{Author Contributions}

The authors, Andree Elias, Wassim N. Shebaby, Bilal Nehme, Wissam Faour, Bassem S. Bassil, Joelle El Hakim, Rita Iskandar, Nahia Dib-Jalbout, Mohamad Mroueh, Costantine Daher, and Robin I. Taleb, declare that they have all contributed significantly in this manuscript to the extent that their contribution warrants their affiliation as one of the contributing authors. Joelle El Hakim, Bilal Nehme, Bassem Bassil and Robin Taleb performed the extraction, isolation and structural characterization of 7-HC. Andree Elias, Joelle El Hakim, Rita Iskandar, Nahia Dib-Jalbout, Wassim Shebaby, Mohamad Mroueh and Costantine Daher performed the cell survival assays. Andree Elias, Wassim N. Shebaby and Wissam Faour performed the isolation and stimulation of monocytes. Andree Elias, Joelle El Hakim, Rita Iskandar, Nahia Dib-Jalbout, Wassim Shebaby, Mohamad Mroueh and Costantine Daher performed the western blot analysis. Wassim Shebaby, Robin Taleb and Costantine Daher performed the monocytes cell survival assay. Drug Combination Index was calculated by Robin Taleb. Rita Iskandar, Nahia Dib-Jalbout, Mohamad Mroueh and Costantine Daher performed the formalin induced paw edema inflammation experiment. Figures and tables were prepared by Wassim Shebaby and Robin Taleb. Manuscript was written by Wassim Shebaby and Robin Taleb and edited by Robin Taleb, Costantine Daher and Mohamad Mroueh.

\section{Additional Information}

Supplementary information accompanies this paper at https://doi.org/10.1038/s41598-019-49374-9.

Competing Interests: I, Robin I. Taleb, declare that the authors have no competing interests as defined by Nature Research, or other interests that might be perceived to influence the results and/or discussion reported in this paper.

Publisher's note: Springer Nature remains neutral with regard to jurisdictional claims in published maps and institutional affiliations.

(c) (i) Open Access This article is licensed under a Creative Commons Attribution 4.0 International Cicense, which permits use, sharing, adaptation, distribution and reproduction in any medium or format, as long as you give appropriate credit to the original author(s) and the source, provide a link to the Creative Commons license, and indicate if changes were made. The images or other third party material in this article are included in the article's Creative Commons license, unless indicated otherwise in a credit line to the material. If material is not included in the article's Creative Commons license and your intended use is not permitted by statutory regulation or exceeds the permitted use, you will need to obtain permission directly from the copyright holder. To view a copy of this license, visit http://creativecommons.org/licenses/by/4.0/.

(C) The Author(s) 2019 